\title{
Mothers' perceptions of care practices for children who underwent heart transplantation
}

\author{
Percepção das mães sobre os cuidados com o filho submetido ao transplante cardíaco \\ Percepción de las madres sobre los cuidados con el hijo sometido al trasplante cardiaco
}

Sarah Maria de Sousa Feitoza', Cristiana Brasil de Almeida Rebouças ${ }^{1}$, Máguida Gomes da Silva², Silvania Braga Ribeiro ${ }^{3}$

\section{How to cite this article:}

Feitoza SMS, Rebouças CBA, Silva MG, Ribeiro SB. Mothers' perceptions of care practices for children who underwent heart. Rev Esc Enferm USP. 2016;50(1):36-42. DOI: http://dx.doi.org/10.1590/S0080-623420160000100005

${ }^{1}$ Universidade Federal do Ceará, Fortaleza, CE, Brazil.

${ }^{2}$ Faculdade Integrada do Ceará, Fortaleza, CE, Brazil.

${ }^{3}$ Hospital Dr. Carlos Alberto Studart Gomes, Fortaleza, CE, Brazil.

\begin{abstract}
Objective: To learn mothers' perceptions of the main care practices that are to be administered after their children's heart transplantation, as well as the main difficulties they experience. Method: A descriptive qualitative study conducted in March and April 2014, using the focus group technique for data gathering. Participants were 12 mothers who were monitoring their children in a hospital that is a reference for treating cardiopulmonary diseases. Speeches were recorded, transcribed, and organized around the care practices that the mothers performed after the children's heart transplantations, the mothers' main difficulties, their perceptions of their children's quality of life, and the use of educational materials to disseminate post-transplantation care practices. For data analysis, we used the content analysis technique. Results: The following were clarified: the schedule of immunosuppressive medication; food, environmental, and bodily and oral hygiene; the use of surgical masks; and keeping the children away from crowds. Conclusion: The study contributed to the situational diagnosis of the care administered by the mothers of transplanted children.
\end{abstract}

\section{DESCRIPTORS}

Heart Transplantation; Child; Mothers; Child Care; Pediatric Nursing.

\section{Corresponding author:}

Sarah Maria de Sousa Feitoza

Rua Alexandre Baraúna, 949 - Rodolfo Teófilo

CEP 60430-160 - Fortaleza, CE, Brazil

sarahfeitoza22@yahoo.com.br
Received: 11/18/2014

Approved: 11/10/2015 


\section{INTRODUCTION}

Heart transplantation is a successful strategy for treating children with terminal cardiac insufficiency, enabling a longer survival and better quality of life. Its long term success is attributed to advances in surgical techniques and immunosuppressive schemes ${ }^{(1)}$. Children with cardiomyopathies since the neonatal period and congenital heart diseases with surgical corrections or not can benefit from heart transplantation. It is a therapeutic alternative when children have a life expectancy below two years and conservative therapies have been exhausted ${ }^{(2-3)}$.

As with any surgical procedure, heart transplantation has complications that parents must be made aware of. There should also be emphasis on the care practices that will be required after transplantation, such as medication schedule, bodily hygiene, feeding, and precautions with the home environment, in addition to the numerous clinic appointments necessary after the procedure. Therefore, we emphasize the need to implement educational actions during nursing appointments so that the mothers can manage their children's care. Even if the mothers already take part in care ${ }^{(4)}$, health education must cause behavior changes for the adoption of a healthy lifestyle.

However, finding strategies to assist transplanted children with the aim of improving quality of life and, consequently, to promote health, is still a serious challenge. The literature shows that in order to overcome challenges in the care of children with chronic issues and to offer humanized, scientific-based care, nurses must use educational technologies to improve care and enable family participation, especially that of the mothers who, in general, take charge of said care in the home environment ${ }^{(5)}$.

The creation of educational technologies must be based on the experiences shared by those responsible for the training and their clients. Therefore, to better understand how mothers incorporate care practices for children with heart transplantations, we used the focus group technique.

Many studies have used the focus group technique to understand assessment processes in everyday practices, actions, facts, and behaviors ${ }^{(6)}$. We found no studies in the literature focusing on mothers' perceptions of care practices after pediatric heart transplantation or even the main difficulties experienced when caring for children with transplants.

This study will be able to contribute to the promotion of health in children who have undergone heart transplantation, in addition to stimulating the possibility of creating printed educational materials based on the mothers' experiences, aggregating the main evidences that support the content's scientific nature.

Thus, we found this study pertinent. The aim was to learn the mothers' perceptions of the main care practices to be administered after their children's heart transplantation, as well as the difficulties they experience after the procedure. The results of this study will be used in the creation of an educational textbook for instructing mothers on the care practices after pediatric heart transplantation, in addition to including the mothers' perceptions of the children's quality of life after the use of written educational materials for disseminating care practices for transplanted children.

\section{METHOD}

This is a descriptive study with a qualitative approach. It is a result of the project Creation and validation of an educational textbook for instructing mothers about post-heart transplantation pediatric care practices.

We used focus groups as one of the stages of data gathering. This is a data gathering technique for groups in which interaction is key, because it makes it possible for participants to explore their points of view on a given subject and generates questions, doubts, or answers in a period no longer than two hours. In general, this interaction works when a member of the group answers another member of the group, expressing agreement or disagreement through questions and when giving or receiving answers. Moreover, there is a multiplicity of ideas and experiences, facilitating the researchers' learning process with the participants ${ }^{(6)}$.

The number of focus group participants might vary from six to 12; participants had, among themselves, at least one common characteristic, which created an intentional sam$\mathrm{ple}^{(6)}$. The participation of a researcher/moderator was necessary during the discussions to introduce the main theme, stimulating the interaction of participants. Along with the moderator, there were observers responsible for describing verbal and non-verbal information ${ }^{(7)}$.

To conduct the group, we searched for a list of mothers of children who underwent heart transplantation and who were being monitored by the pediatric clinic team in a public hospital located in the capital of the state of Ceará. This hospital is a reference for cardiopulmonary diseases, with an emphasis on adult and pediatric heart transplantation. It is worth noting that the meetings were scheduled for the days when the children had follow-up appointments. Twelve mothers participated in the study. On the day before the appointment, we telephoned the mothers to confirm it. All mothers who came to the hospital on the scheduled days for the groups and who accepted to participate in the study were included, regardless of when their children had their transplantation.

There were two focus group sessions. These occurred on Fridays in the hospital's meeting auditorium, from March until April 2014. The first session was conducted with eight mothers and the second with four, because two mothers did not come to their appointments. It is worth noting that the chairs were organized in circles to promote visual contact and favor the mothers' interaction ${ }^{(7)}$. While the mothers where in the group session, the children remained in the adjacent auditorium with a clinic worker, playing with toys, stickers, and drawings.

After presenting the aims of the research, we used a script with the following focal questions: Are you satisfied with the surgery's result? What difficulties did you experience after your child's heart transplantation? How do you evaluate your child's quality of life today? Is there something decreasing their quality of life? Which care actions do you consider important to conduct after the transplanta- 
tion? How do you see the use of educational materials that facilitate the understanding of required care actions after heart transplantation? The length of the focus groups varied from 40 minutes to one hour.

Speeches were recorded, transcribed, and organized around the care practices that the mothers performed after the children's heart transplantations, the mothers' main difficulties, the mothers' perceptions of their children's quality of life, and the use of educational materials to disseminate post-transplantation care practices. For data analysis, we used the content analysis technique, which seeks meanings found in documents, field notes, and recorded interviews ${ }^{(8)}$. This enabled the identification of thematic categories through the words of the study's subjects, thus enabling a better comprehension of the problem at hand.

We respected the ethical and legal principles for research on human beings recommended by Resolution 466/2012. The study was approved by the Ethics Committee under number 543.751 from 2014. All participants signed a Free and Informed Consent Form after learning about the aims of the study and its data gathering technique. When presenting the speeches, participants were coded with the letter $\mathrm{P}$ (for Participant) and a number from 1 to 12 for each subject in order to preserve their identities.

\section{RESULTS}

The participant group was composed as follows: the mothers' average age was 30.5 years. All of them lived in the state's countryside but had residences in the city where their children were monitored after transplantation. Regarding their civil status, six (50\%) women were married and/or in a consensual union. Information on education by years revealed that there was a predominance of five to eight years of study (41.6\%). The investigation on monthly family income showed a predominance of up to two minimum wages.

As for data on transplanted children, eight children were female and seven children were aged between two and 15 . Six children (50\%) had a family history of coronary diseases; some mothers identified other heart diseases in the children's families, but were not able to say whether there were congenital diseases among them. The predominant age group for when the transplantation happened was between 10 and 15 years, with seven children (58.3\%). Of these, five (41.6\%) were transplanted when they were aged between one and five. Rejection and infections were the complications most frequently mentioned by the mothers.

Analysis of the empirical material revealed the following thematic categories: Care practices to be observed after transplantation; Difficulties experienced after the children's heart transplantation; Quality of life of the children after transplantation; and Written educational material.

\section{Care PRACTICES to be ObServed AFter transplantation}

For the mothers, hygiene was considered essential in their home routine, especially in the bedroom, including sheets, individual bathrooms, and disinfection of objects with alcohol. We emphasize the influence of maintaining these care practices to support the health of transplanted children. They have their own bedroom. The bathroom must be washed every day. If there is a dresser, it must be cleaned with alcohol. If there is a fan, it must be cleaned at dusk. The room must not be swept, only cleaned with a piece of cloth so that dust does not come up and get stuck to something. Furniture, bed, everything is cleaned with alcohol and cloths. Every day, I wake up and wash the bathroom so it is clean when she uses it, and the bathroom is only hers, but it still must be washed every day (P1).

Food hygiene is one of the essential care practices because of the immunosuppression that results from the use of medication. Some opportunistic diseases use the mouth as entrance through contaminated food.

For her to eat an apple, I have to wash it with water and then feed it to her. Transplanted children are transplanted. You have to put sodium hypochlorite in a bowl with water, two drops (P2).

Beans, if they are for eating, you can make the beans for lunch and they will eat those beans and eat them again for dinner, but if some of it was not eaten, you cannot serve it tomorrow. Food has to be prepared on demand (P2).

Immunosuppressive medication requires a two-hour interval before and after eating, so it is necessary for the mothers to be aware of their children's food control.

He can only eat until 7:50 PM; then he will only eat again after 10 PM, because of the medication. It should be taken two hours before and two hours after (P3).

Precautions with oral hygiene help prevent diseases that can compromise the graft. Moreover, use of immunosuppressive medication facilitates the emergence of gingivitis and mucositis that make it harder to clean the mouth, because children feel pain when brushing their teeth.

His teeth are very small, the gum is very big and the teeth is bidden inside because of the medication he takes, according to the doctor who informed me (P11).

It hurts his mouth. The teeth are very small, because of that, some of them do not come out, they stay inside the gum and hurt him. The medicine they take hurts them, but they have to take it (P10).

We have to encourage them to brush their teeth and take the medication prescribed by the doctor to clean their mouth (P10).

After transplantation, the children must avoid crowds and wear surgical masks whenever they enter a hospital or come in contact with other people:

Environments with lots of people, I worry too much, because they ask to remove the mask after the third month, according to the doctor. So I feel doubtful when there are a lot of people around. We have to be careful when someone has the flu, because sometimes people come close and end up transmitting the disease (P2).

Yes, I try to avoid exposing him too much, to not go out too much. I think that contact with crowds, especially for him, who just had a transplantation, their immunities, in general, are very low (P10). 
DifFICULTIES EXPERIENCED AFTER THE CHILDREN'S HEART TRANSPLANTATION

This category gathers subjects related to issues such as finance, daily hygiene of the environment, resistance by the children to accept their condition after the transplantation, and living in other cities. These were mentioned as the main difficulties experienced by the mothers.

In the following speeches, we observe how the financial issue is a limiting factor for mothers who live in other cities, given the absence of support networks close to the hospital. This demands a new domiciliary structure that meets the demands of transplanted children. Moreover, the children's current situation demands the recommended nutrition.

The financial issue, the hygiene issue, the issue of their environment (...). It is very hard to keep all of this up. And we know that for them to have a good life, healthy, this is all necessary, isn't it? (P1).

I spent nine months here, just I and her, already because I didn't have anyone to stay with her. So I had to rent an apartment here, with no financial conditions, I paid 500 reais. The lowest price I found was that one, the cheaper one (P4).

Those who have the financial conditions to live here end up living here because it is better. But most can't (P5).

Food is very expensive. You take 200 reais or 300 reais, thinking it'll be enough, or you have to keep note of what you're spending, you have to check prices, taking care to not go over the limit $(\mathrm{P} 4)$.

Children do not understand some limitations and precautions that should be observed after the surgery, which demands constant attention from the mothers, as shown in the following speeches:

(...) because you have to pay attention all the time. "You are here, you have to stay close." Because they can't eat at certain times. Sometimes in a lapse you go out and the child thinks: "I am hungry." If somebody is there, they say "Take this," or if you're eating and offer it to the child, she will take it. In the past, I had given her the medication and my mother was eating when she said "Look, eat some of this!" I was paying attention, so I said "No, stop!" (P4).

Not mentioning what P1 said, which is true, we have to make them understand that they are children. You can't eat this, you can't do that, you have a fasting time to take your medication, this you can't eat, the nutritionist does not allow this, you can't go to the beach (...). The problem is convincing a child that they can't be the same as the other ones at that time (P2).

\section{QUALITY OF LIFE OF THE CHILDREN AFTER TRANSPLANTATION}

The mothers mentioned that, despite the continuous attention and constant risk of complications after the transplantation, hospital admissions decreased and the children rarely suffered edemas, as shown in the speeches below:

She improved a lot. She was very sick, irritable, didn't used to play, didn't use to do anything. Now she does everything (P2).
My (daughter), thank God, is well. Before the transplantation she underwent seven surgeries, she wasn't able to sit, and then came the time for her to undergo transplantation. She was swollen all the time. After she had the transplantation, thank God, everything is fine, she is already studying, thank God (P3).

She couldn't stay out of the hospital, be discharged. And after the transplantation, two months later she was discharged, went home. Then, when there are some alterations in her exams, she takes the medication and then it's $O K(\mathrm{P} 9)$.

\section{WRITTEN EDUCATIONAL MATERIAL}

This category addressed the need for the guidelines received after the transplantation to be didactic, with images and reminders - in other words, material that makes it easier to disseminate care practices, to be shown to the family, and to teachers and other professionals responsible for the children, as shown by the speeches:

I think it's nice. I, for example, want to go back to work; I really miss my work. And then, this will help me when I leave him with someone else. I can explain everything (P9).

For me, it's her school. We will explain where many schools do not want to accept, because she is so young. She dreamed about studying (P10).

\section{DISCUSSION}

Knowledge about care practices, difficulties, and perceptions of the children's quality of life is very relevant when planning post-transplantation nursing assistance in the sense of giving authentic information and decreasing the mothers' stress and anxiety.

Participating mothers had full physical capabilities, which made them able to endure the frequent trips and adaptations that are necessary to improve their children's condition. The low education among participating mothers was a troubling factor, because it is directly linked to the degree of understanding and performance of guidelines and care practices after the children's transplantation.

These children faced the reality of a chronic condition early in their lives: the numerous hospital admissions until their condition's evolution into a state that resists clinical treatment, with transplantation remaining as the only therapeutic alternative ${ }^{(2)}$. After transplantation, rejection is one of the main causes of death among children in the first year following the transplant; its appearance is strongly linked to a lack of adherence to immunosuppressive treatment ${ }^{(3)}$.

The use of immunosuppressive medication is essential so that the adaptation of the new heart is adequate, decreasing the chances of graft rejection. However, the medication leads to a compromise of the immune system, increasing the probability of infections that remain an important cause of morbidity and mortality, being responsible for approximately $12 \%$ of deaths during the first year after transplantation $^{(9)}$. The most common immunosuppressive medication for children is tracolimus. When it is used in the home environment, it is important that the mothers 
either observe the two-hour period after eating or have the children fast ${ }^{(3)}$.

Infection processes can be transmitted to the heart through blood and its derivatives, and by the microbiota and reactivation of latent infections. In addition to these, there are situations inherent to the environment, including feeding ${ }^{(10)}$. Therefore, precautions with the cleaning and cooking of food are essential for the prevention of parasitic infections ${ }^{(11)}$.

The environment in which transplanted children live also needs daily precautions in order to be kept clean and to avoid contaminants that result in sickness. This demands some rooms of the house to be exclusively for transplanted children. One of the products recommended for disinfecting surfaces is alcohol which, when used directly on infected surfaces, has results similar to when there is a previous cleaning to apply alcohol $70 \%$ afterwards ${ }^{(12)}$.

Oral cavity infections after transplantation are troubling, because the oral mucosa is an open environment that allows the entrance and exit of a number of microorganisms. Immunosuppression can cause the growth of local microbiota; thus good oral hygiene and the eradication of dental diseases are effective preventive measures for the decrease of daily bacteremia ${ }^{(13)}$.

The development of gum hyperplasia as a side effect of some immunosuppressive drugs can manifest with greater intensity due to the presence of bacterial plaque and make it harder to satisfactorily clean the mouth ${ }^{(14)}$. Prescribing oral nystatin helps to prevent infections in the oral cavity, especially by fungus. The use of surgical masks and the restriction of contact with other people help to prevent other opportunistic infections.

One of the aspects to be considered after the children's cardiac transplantation is immunization. Although it was not mentioned in the mothers' speeches, this is one of the care practices that deserve the most attention, because the children should not be vaccinated with live or attenuated agents, and vaccination in the first six months after the transplantation must be avoided altogether ${ }^{(3)}$.

The financial issue, mentioned as one of the main difficulties after transplantation, is justified by changes in family dynamics and different types of handling and adaptation that the family system develops when experiencing pediatric transplantation, especially for families who live in other cities $^{(15)}$. We notice that transplantation itself is not the only concern, because financial support has to be adequate to enable care for transplanted children. Mothers tried strategies to better adapt to the needs of their children so that they can address new financial problems. Therefore, not only does the mothers' role deserve special mention, but the family's as well, which results in a support network, both emotional and financial ${ }^{(16-17)}$.

The home environment is an aspect to be considered before the child is placed in line for cardiac transplantation, because when they are summoned for the surgery, they have to be at the hospital within two hours. In addition, analyzing the variables of income and education helps in the identification of socioeconomic and cultural factors that may represent risks for the children after transplantation ${ }^{(3)}$.

Another problem for the mothers is handling the behavior of their transplanted children, who frequently do not understand the magnitude of the risks when behaving in certain ways that may result in rejection of the graft. The treatment protocol causes interference in school, leisure, and social activities, which can lead to a lack of adherence ${ }^{(18)}$. Children do not easily understand that they can lead a normal life, even if it is limited.

One study showed that, when asked about their quality of life post-transplantation, children answered the opposite of what was expected, because there is a resistance to accepting later clinic monitoring, which represents a negative point for their health. Parents answered that they considered their children's health normal after transplantation ${ }^{(19)}$.

Improvement in symptoms such as effort dyspnea and edema after transplantation makes the parents see their children's health as adequate because of the increase in survival rate and improvements in the quality of life of these children, who carry complex heart diseases and cardiomyopathies that do not respond to standard treatment ${ }^{(20)}$.

The children's adaptation becomes physiologically adequate because the transplanted heart has normal growth in diastolic dimensions, volume, and myocardial size as time passes, adequate for the organism's growth after the heart transplantation $^{(21)}$.

However, informing the mothers is not enough for the information to be processed. It is necessary that they understand the message transmitted by health workers in order to handle their children's post-transplantation difficulties.

A study conducted at the University of Pittsburgh helped develop an educational program about the critical aspects of heart transplantation, as well as the treatment routine, including the use of printed educational materials for preparing pediatric patients and their families. A questionnaire was used to assess their knowledge before and after receiving the educational material and it was found that parents shared and discussed information at home with other family members, in addition to changes in the behavior of the children ${ }^{(22)}$.

The educational process must be established gradually, continuously, and interactively with the mothers of transplanted children, because there is a demand for information about individual care practices for these children, especially in the home environment.

Nursing assistance offered continuously and with qualification, using health education as an activity for the promotion of health, contributes to rehabilitation from surgical procedures such as heart transplantation.

After learning these mothers' perceptions, it is possible to assess what must be added as new guidelines, as well as to encourage the creation of written educational materials that support the mothers' learning before surgery about care practices at home after surgery. This strengthens the trust bonds with the health team, which is essential to ease anxiety and encourage trustfulness and readiness when following the proposed treatment, in addition to decreas- 
ing possible complications after transplantation. However, among future perspectives, we have the construction and validation of an educational textbook to guide care practices after pediatric heart transplantations.

As a limitation of the study, we highlight the lack of focus groups with mothers of children who are still waiting for surgery. In the gathering period only two children were waiting for transplantation. We suggest additional studies with mothers of children who are waiting for surgery, which would make it possible to answer questions and add information through written educational materials.

\section{CONCLUSION}

This study enabled the identification of mothers' perceptions of the care practices for their transplanted children, as well as their difficulties, and the importance of having written material that disseminates the main guidelines for the care of their children. It contributed to a situational diagnosis of the care administered by the mothers of transplanted children, with emphasis on: the schedule of immunosuppressive medication; food, environmental, and bodily and oral hygiene; the use of surgical masks; and keeping the children away from crowds.

\section{RESUMO}

Objetivo: Conhecer a percepção das mães acerca dos principais cuidados a serem executados após o transplante cardíaco do filho, assim como as principais dificuldades por elas vivenciadas. Método: Estudo descritivo, qualitativo, realizado em março e abril de 2014 por meio da técnica de grupo focal para a coleta de dados. Participaram 12 mães que estavam acompanhando seu filho em um hospital de referência em doenças cardiopulmonares. Os depoimentos foram gravados, transcritos e organizados em torno dos cuidados que as mães realizaram após o transplante cardíaco da criança, das principais dificuldades das mães, da percepção das mães sobre a qualidade de vida das crianças e sobre a utilização de materiais educativos para divulgação dos cuidados após o transplante. Para a análise dos dados foi utilizada a técnica de análise do conteúdo. Resultados: Entre os assuntos abordados destacam-se: o horário das medicações imunossupressoras, a higiene dos alimentos, a limpeza do ambiente, a higiene corporal e oral, o uso de máscara cirúrgica, e o cuidado em manter a criança longe de aglomerados de pessoas. Conclusão: O estudo contribuiu para o diagnóstico situacional quanto aos cuidados realizados pelas mães de crianças transplantadas.

\section{DESCRITORES}

Transplante de Coração; Criança; Mães; Cuidado da Criança; Enfermagem Pediátrica.

\section{RESUMEN}

Objetivo: Conocer la percepción de las madres acerca de los principales cuidados que se deben tener después del trasplante cardiaco del hijo, así como las principales dificultades por ellas vividas. Método: Estudio descriptivo, cualitativo, llevado a cabo en marzo y abril de 2014 por medio de la técnica de grupo focal para la recolección de datos. Participaron 12 madres que estaban acompañando a su hijo en un hospital de referencia en enfermedades cardiopulmonares. Las declaraciones fueron grabadas, transcritas y organizadas acerca de los cuidados que las madres realizaron después del trasplante cardiaco del niño, las principales dificultades de las madres, la percepción de las madres sobre la calidad de vida de los niños y la utilización de materiales educativos para divulgación de los cuidados luego del trasplante. Para el análisis de los datos se utilizó la técnica de análisis de contenido. Resultados: Entre los temas abordados se destacan: el horario de los medicamentos inmunosupresores, la higiene de los alimentos, la limpieza del ambiente, la higiene corporal y oral, el uso de mascarilla quirúrgica y el cuidado en mantener al niño lejos de aglomeraciones de personas. Conclusión: El estudio contribuyó al diagnóstico situacional en cuanto a los cuidados realizados por las madres de niños trasplantados.

\section{DESCRIPTORES}

Trasplante de Corazón; Niño; Madres; Cuidado del Niño; Enfermería Pediátrica.

\section{REFERENCES}

1. Vanderlan RD, Manlhiot C, Conway J, Honjo O, McCrindle BW, Dipchand AL. Perioperative factors associated with in-hospital mortality or retransplantation in pediatric heart transplant recipients. J Thorac Cardiovasc Surg. 2014;148(1):282-9.

2. Tjang YS, Stenlund H, Tenderich G, Hornik L, Körfer R. Pediatric heart transplantation: current clinical review. J Card Surg. 2008;23(1):87-91.

3. Bacal F, Souza-Neto JD, Fiorelli AI, Mejia J, Marcondes-Braga FG, Mangini S, et al. II Diretriz Brasileira de Transplante Cardíaco. Arq Bras Cardiol. 2009;94(1 Supl.1):e16-e73.

4. Lerret SM, Weiss ME. How ready are they? Parents of pediatric solid organ transplant recipients and the transition from hospital to home following transplant. Pediatr Transplant. 2011;15(6):606-16.

5. Silveira A, Neves ET. Crianças com necessidades especiais em saúde: cuidado familiar na preservação da vida. Ciênc Cuid Saúde. 2012;11(1):74-80.

6. Backes DS, Colomé JS, Erdmanm RH, Lunardi VL. Grupo focal como técnica e análise de dados em pesquisas qualitativas. Mundo Saúde. 2011;35(4):438-42.

7. Santos MRM, Sousa CS, Turrinl RNT. Perception of orthognathic surgery patients on postoperative care. Rev Esc Enferm USP [Internet]. 2012 [cited 2014 Oct 20];46(n.spe):78-85. Available from: http://www.scielo.br/pdf/reeusp/v46nspe/en_12.pdf

8. Campos CJG, Turato ER. Content analysis in studies the clinical-qualitative method: application and perspectives. Rev Latino Am Enfermagem. 2009;17(2):259-64.

9. Thursh, PT, Hoffman TM. Pediatric heart transplantation-indications and outcomes in the currentera. J Thorac Dis. 2014;6(8):1080-96. 
10. Majhail NS, Rizzo D. Surviving the cure: long term followup of hematopoietic cell transplant recipients. Bone Marrow Transplant. 2013;48(9):1145-51.

11. Mofenson LM, Brady MT, Danner SP, Dominguez KL, Hazra R, Handelsman E, et al. Guidelines for the prevention and treatment of opportunistic infections among HIV-exposed and HIV-infected children: recommendations from CDC, the National Institutes of Health, the HIV Medicine Association of the Infectious Diseases Society of America, the Pediatric Infectious Diseases Society, and the American Academy of Pediatrics. MMWR Recomm Rep. 2009;58(RR11):1-166.

12. Graziano MU, Graziano KU, Pinto FMG, Bruna CQM, Souza RQ, Lascala CA, et al. Effectiveness of disinfection with alcohol $70 \%$ (w/v) of contaminated surfaces not previously cleaned. Rev Latino Am Enfermagem. 2013;21(2):618-23.

13. Marra M, Silva Júnior O, Pereira VC, Marcussi DM, Cunha TMP; Melo CS. Odontologia em pacientes portadores de dispositivos cardíacos eletrônicos implantáveis (DCEI). Relampa [Internet]. 2009 [citado 2014 out. 20];22(3):125-9. Disponível em: http://www.relampa.org.br/ detalhe_artigo.asp?id=682

14. Cunha CB, Souza ECA, Shitara PPL, Santos PSS, David LL. Avaliação da condição de saúde bucal de pacientes em programa de transplante de órgãos sólidos. JBT J Bras Transpl. 2010;13(4):1393-448.

15. Penaforte KL, Araújo ST, Campos ACS, Rolim KMC, Santos FLM. Transplante cardíaco infantil: perspectivas e sentimentos maternos. Esc Anna Nery. 2009;13(4):733-40.

16. Uzark k, Griffin L, Rodriguez R, Zamberlan M, Murphy P, Nasman C, et al. Quality of life in pediatric heart transplant recipients: a comparison with children with and without heart disease. J Heart Lung Transplant. 2012;31(6):571-8.

17. Kim JJ, Marks SD. Long-term outcomes of children after solid organ transplantation. Clinics. 2014;69(S1):28-38.

18. Green A, Ray T. Attention to child development: a key piece of family-centered care for cardiac transplant recipients. J Spec Pediatr Nurs. 2006;11(2):143-8.

19. Green A, McSweeney J, Ainley K, Bryant J. Comparing parent's and children's views of children's quality of life after heart transplant. J Spec Pediatr Nurs. 2009; 14(1): 49-58.

20. Santos AA, Silva JP, Fonseca L, Baumgratz JF. Heart retransplantation in children without the use of blood product. Rev Bras Cir Cardiovasc. 2012;27(2):327-30.

21. Delmo Walter EM, Huebler M, Stamm C, Alexi-Meskishvili V, Weng Y, Berger F, et al. Adaptive growth and remodeling of transplanted hearts in children. Eur J Cardiothorac Surg. 2011;40(6):1374-82.

22. Lawrence KS, Stilley CS, Pollock JA, Webber SA, Quivers ES. A family-centered educational program to promote independence in pediatric heart transplant recipients. Prog Transplant. 2011;21(1):61-6. 